\title{
METODE BERMAIN BERPERAN DALAM PERKEMBANGAN MORAL ANAK
}

\author{
Eka Damayanti \\ Universitas Islam Negeri Alauddin Makassar \\ E-mail: eka.damayanti@uin-alauddin.ac.id \\ Yuspiani \\ Universitas Islam Negeri Alauddin Makassar \\ E-mail: yuspiani @uin-alauddin.ac.id \\ Nur Intan Tri Rejeki \\ Universitas Islam Negeri Alauddin Makassar \\ E-mail: nurintantri018@gmail.com \\ Ade Agusriani \\ Universitas Islam Negeri Alauddin Makassar \\ E-mail: ade.agusriani@uin-alauddin.ac.id \\ Nurhasanah \\ Universitas Islam Negeri Alauddin Makassar \\ E-mail: nurhasanahsultan077@gmail.com
}

\begin{abstract}
Abstrak
Penelitian ini bertujuan untuk mengetahui peran metode bermain pada perkembangan moral anak. Penelitian dilakukan menggunakan pendekatan kualitatif jenis studi pustaka (library research). Pengumpulan data menggunakan dokumentasi dari buku ataupun karya ilmiah jurnal yang relevan. Data dianalisis menggunakan narasi deskriptif. Hasil penelitian menunjukkan adanya peran metode bermain pada perkembangan moral anak. Bermain dapat mendorong anak memiliki kemampuan mengekspresikan dan mengontrol emosi, sikap empati, adil, tidak membedabedakan dalam berteman, memiliki kesadaran akan hak dan tanggungjawab serta mampu menghargai cara berpikir orang lain yang berbeda dengan dirinya. Jenis permainan yang paling berperan dalam peningkatan perkembangan moral anak yakni bermain peran. Hasil penelitian mengimplikasikan kepada orangtua, guru atau pengasuh untuk senantiasa memberikan stimulasi permainan pada anak khususnya bermain peran agar perkembangan moralnya mengalami peningkatan.
\end{abstract}

Kata Kunci: Anak Usia Dini, Bermain, Perkembangan Moral

\section{Abstrack}

This study aims to determine the role of playing methods in children's moral development. The research was conducted using a qualitative approach type of literature study (library research). Data collection used documentation from 
books or relevant journal scientific papers. Data were analyzed using the descriptive narrative. The results showed the role of playing methods in children's moral development. Playing can encourage children to have the ability to express and control emotions, empathy, be fair, do not discriminate in friends, have an awareness of rights and responsibilities, and can respect the way of thinking of others who are different from themselves. The game type that in improving children's moral development was role-playing. It appears that parents, teachers, or caregivers always stimulate children, especially playing roles to increase their moral development.

Keywords: Early Childhood, Play, Moral Development

\section{PENDAHULUAN}

Pendidikan adalah suatu proses pembelajaran yang melibatkan peserta didik dan pendidik untuk membangun pemahaman dan kemampuan menjadi seseorang yang kritis dalam berfikir. Tujuan dari pendidikan adalah untuk mencerdaskan dan mengembangkan potensi dari peserta didik. Sejalan dengan Pratiwi (2017) bahwa pendidikan adalah usaha sadar yang dengan sengaja dirancang untuk mencapai tujuan yang telah ditetapkan sebagaimana tujuan pendidikan nasional adalah untuk mencerdaskan kehidupan bangsa.

Pendidikan di sekolah mempunyai tujuan untuk membentuk peserta didik memiliki pengetahuan, keterampilan dan sikap pelajar sebagai bentuk perubahan perilaku hasil belajar. Perubahan tersebut menurut Sartika (2016) umumnya dilakukan oleh guru dengan menggunakan beberapa metode dan kegiatan praktek untuk menunjang proses belajar mengajar, sehingga anak terlibat aktif. Indonesia telah membuat aturan mengenai pendidikan anak usia dini yang dimuat dalam Undang-undang Nomor 20 Tahun 2003 tentang Pendidikan Nasional Pasal 1 ayat 14 bahwa "Pendidikan Anak Usia Dini (PAUD) adalah salah satu upaya pembinaan yang ditujukan kepada anak sejak lahir yang dilakukan melalui pemberian rangsangan pendidikan untuk membantu pertumbuhan dan perkembangan jasmani dan rohani"

Aspek perkembangan moral merupakan salah satu aspek yang perlu distimulasi pada anak usia dini. Sartika (2016) menyatakan bahwa perkembangan moral berkaitan dengan perilaku, perasaan dan tingkah laku benar dan salah. Haris (Sit, 2010) memaparkan moral merupakan perilaku yang berhubungan dengan halhal yang benar dan salah, baik dan buruk, serta tugas dan kewajiban. Masa usia dini merupakan masa yang paling tepat untuk mengembangkan aspek perkembangan moral anak karena moral yang dibentuk dari awal atau dari sejak usia dini, akan terbawa sampai anak beranjak dewasa.

Putri (2018) mengungkapkan perkembangan nilai-nilai moral dan agama pada anak sangat erat kaitannya dengan budi pekerti, sikap sopan santun, patuh kepada orang tua dan guru dalam kehidupan sehari-hari. Potensi tersebut dapat berkembang secara optimal melalui pemberian rangsangan melalui kegiatan 
pembiasaan rutin dan keteladanan yang dilakukan sehari-hari. Hal yang sama dikemukakan Ananda (2017) bahwa masa usia dini ialah masa dimana anak masih sangat labil, mudah terbawa arus, dan mudah terpengaruh. Oleh karena itu, penting bagi pendidik atau orangtua untuk memberikan stimulasi atau rangsangan, pengajaran atau bimbingan, serta pembiasaan secara terus menerus kepada anak. Holis (2016) mengatakan bahwa stimulasi harus disiapkan oleh pendidik, baik orangtua, guru, pengasuh atau orang dewasa lain yang ada disekitar anak, sehingga anak memiliki kesempatan untuk mengembangkan seluruh potensi yang dimiliki oleh anak.

Bentuk stimulasi yang dilakukan oleh guru di lingkungan sekolah dapat terlihat dalam metode pembelajaran yang diberikan. Menurut Palah \& Soe'aiddy (2019) metode pembelajaran adalah salah satu komponen penting karena dapat memudahkan pemahaman peserta didik dalam menerima pelajaran. Lestari (2017) menyatakan keberhasilan dalam belajar bisa dilihat dari dua indikator yaitu keaktifan siswa selama proses belajar mengajar dan hasil belajar yang didapat siswa pada akhir pembelajaran yang bisa berwujud kemampuan mengerjakan tugas dan perubahan sikap.

Mengubah sikap atau perilaku anak menjadi lebih bermoral juga memerlukan metode yang tepat karena menurut Febriana (2018) pendidikan moral inilah yang akan membentuk anak menjadi pribadi yang berkarakter baik. Menurut Rohmah (2016) moralitas pada anak usia dini merupakan hal yang abstrak dan sulit untuk didefinisikan, sehingga untuk mengenalkan moral pada anak diperlukan cara yang mudah dipahami atau dimengerti oleh anak, salah satunya yaitu melalui kegiatan bermain. Bermain dapat membantu anak untuk memahami perannya sendiri dan peran yang dimainkan orang lain sambil memahami perasaan, sikap dan nilai yang dimainkannya. Melalui bermain, anak dapat berinteraksi dengan teman-temannya yang juga memainkan peran tertentu sesuai dengan tema yang dipilih. Selama pembelajaran berlangsung, setiap pemeran dapat melatih sikap empati, simpati, rasa benci, marah, senang, dan melakukan hal berkaitan dengan pembentukan moral.

Farhurohman (2017) memaparkan bahwa melalui permainan, anak akan memperoleh berbagai macam pengalaman yang menyenangkan, sambil belajar dan melaksanakan tugas-tugas perkembangan. Erfayliana (2016) mengatakan bahwa untuk mendukung perkembangan anak baik secara fisik maupun psikis anak membutuhkan bermain karena dalam bermain anak mempunyai kebebasan untuk menyalurkan dan mengekspresikan dirinya.

Berdasarkan beberapa teori diatas, dapat disimpulkan metode bermain merupakan salah satu metode yang dapat digunakan dalam meningkatkan aspek perkembangan moral anak. Oleh karena itu, kehadiran artikel ini untuk membuktikan secara ilmiah peran bermain pada perkembangan moral anak. Artikel ini diharapkan dapat menjadi rujukan bagi orangtua, pendidik atau pengasuh untuk 
menciptakan berbagai aktivitas bermain baik pada anak baik di rumah maupun di sekolah agar anak memiliki moral yang kuat.

\section{METODE PENELITIAN}

Penelitian ini menggunakan pendekatan kualitatif jenis studi pustaka (Library Research) yaitu metode yang memperoleh data dari buku yang relevan ataupun karya ilmiah lainnya yang berhubungan dengan masalah tersebut. Penelitian ini berfokus pada peran metode bermain dalam perkembangan moral anak.

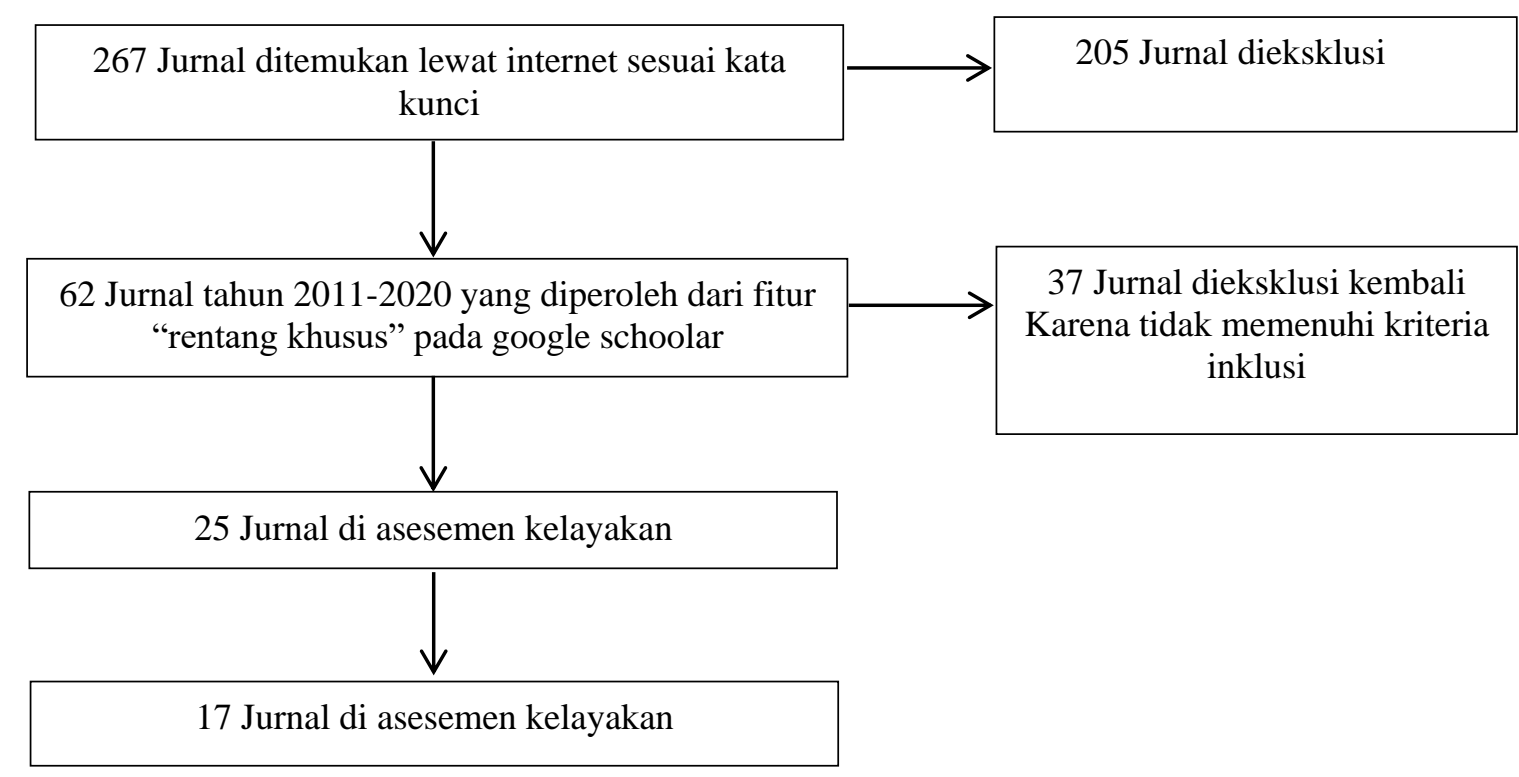

\section{Gambar 1 \\ Diagram Alur Pemilihan Jurnal}

Pengumpulan data dilakukan dengan studi pustaka, yaitu pengumpulan data yang diarahkan kepada pencarian dokumen atau informasi sebagai bahan rujukan yang bersumber dari buku, makalah, artikel jurnal, maupun karya ilmiah yang relevan dengan penelitian yang dilakukan. Penelitian ini dilakukan dengan menelaah dan membandingkan sumber kepustakaan untuk memperoleh data yang bersifat teoritis. Analisis data pada penelitian ini mulai dari reduksi data yaitu sebagai proses penyederhanaan data atau mengambil inti dari data, kemudian menyajikan atau mendisplay data, dan konklusi atau memverifikasi data.

\section{HASIL DAN PEMBAHASAN}

Berdasarkan berbagai referensi hasil penelitian sebelumnya yang fokus pada metode bermain dan perannya pada perkembangan moral anak, berikut ini peneliti paparkan temuan pokok hasil penelitian: 


\section{Bermain dapat mengoptimalkan seluruh perkembangan anak}

Anak sebagai generasi penerus bangsa perlu memeroleh pendidikan yang baik agar potensi dirinya dapat berkembang dengan optimal. Oleh karena itu penting bagi lembaga dan keluarga untuk berperan dan bertanggung jawab dalam memberikan berbagai macam stimulasi dan bimbingan yang tepat sehingga akan terwujud generasi penerus yang berakhlak dan bertingkah laku sesuai dengan norma. Pengembangan nilai-nilai moral dan agama anak usia 5-6 tahun bisa dilakukan dengan berbagai macam metode antara lain bernyanyi, bermain, karyawisata, outbond, bermain peran, bercerita, bersyair, dan keteladanan (Anggraini \& Syafril, 2018).

Hasil penelitian dari The Smithsonian Institute menunjukkan bahwa pembelajaran dalam PAUD akan berlangsung efektif bila menggunakan pendekatan konkret dan melalui kegiatan bermain (Yus, 2014). Menurut Khaironi (2017) hakikat belajar anak usia dini yaitu anak belajar melalui bermain. Bermain merupakan suatu proses belajar untuk memperoleh berbagai informasi dan menjawab rasa ingin tahu anak. Untuk membangun pengetahuan, mengembangkan keterampilan, dan membina akhlak terpuji dapat dilakukan anak melalui aktivitas bermain dimana aktivitas bermain sebagai sumber belajar anak. Mardiono (2008) mengatakan bahwa dunia anak merupakan dunia bermain, sehingga guru dapat menciptakan permainan yang menyenangkan bagi anak. Melalui bermain guru dapat menanamkan nilai moral, misalnya mengajarkan anak untuk menerima kekalahan dengan lapang dada.

Menurut Pratiwi (2017) kegiatan bermain merupakan kegiatan yang menyenangkan bagi anak dan dapat mengoptimalkan seluruh aspek perkembangan anak. Anak akan belajar dan menyerap pengalaman yang didapatkannya melalui bermain sehingga dapat memperoleh pengetahuan tentang lingkungan dan sekitarnya yang dapat bermanfaat bagi anak dalam mengembangkan kemampuan yang ada dalam dirinya dikemudian hari. Dalam konsep Developmentally Appropriate Practice (DAP), anak membentuk pemahaman mereka sendiri terhadap pengalaman melalui pendekatan konkret atau pengalaman fisik. Melalui bermain maka anak belajar untuk memahami dunia, berhubungan dengan orang lain dalam cara-cara sosial, mengekspresikan dan mengontrol emosi, serta membangun kemampuan simboliknya.

Menurut Sugianto (2018) bermain tidak tertuju pada hasil kegiatan tetapi pada proses saat anak bermain, melalui bermain anak-anak mendapatkan pemenuhan kebutuhan yang berkaitan dengan aspek perkembangannya. Supartini (Putri, 2018) mengatakan bahwa anak akan belajar memberi dan menerima melalui kegiatan bermain. Bermain dengan orang lain akan membantu anak untuk mengembangkan hubungan sosial dan belajar memecahkan masalah dari hubungan tersebut. Pada saat melakukan aktivitas bermain, anak belajar berinteraksi dengan teman, memahami bahasa lawan bicara, dan belajar tentang 
nilai sosial.

Pada tahap perkembangana anak, bermain memberikan pengaruh yang besar terhadap perkembangan anak. Dengan bermain, anak akan melakukan percobaan tertentu dan melakukan eksplorasi, sambil menguji kemampuannya. Melalui permainan, anak akan memperoleh berbagai macam pengalaman yang menyenangkan, sambil belajar dan melaksanakan tugas-tugas perkembangan (Farhurohman, 2017). Erfayliana (2016) mengatakan bahwa untuk mendukung perkembangan anak baik secara fisik maupun psikis anak membutuhkan bermain karena dalam bermain anak mempunyai kebebasan untuk menyalurkan dan mengekspresikan dirinya.

\section{Perkembangan moral merupakan aspek penting yang perlu distimulasi}

Gunarsa \& Gunarsa (2008) menyatakan bahwa istilah moral berasal dari kata latin mos (moris) yang berarti adat istiadat, kebiasaan dan tata cara kehidupan. Suatu perilaku dikatakan bermoral apabila perilaku tersebut sesuai dengan nilainilai moral yang berlaku dalam suatu kelompok sosial tertentu. Nilai nilai moral tidak sama pada semua masyarakat, karena pada umumnya nilai-nilai moral dipengaruhi kebudayaan dari kelompok atau masyarakat itu sendiri.

Hasil penelitian Nurjanah (2018) menyimpulkan bahwa perkembangan moral anak tidak lepas dari peran orangtua, pendidik dan lingkungan sekitar. Pranoto (2017) mengatakan bahwa perkembangan moral anak dibangun sejak dini dimulai dari keluarga dan pada saat memasuki usia sekolah, pendidik menjadi turut berperan dalam memfasilitasi perkembangan moral anak. Inawati (2017) menyatakan bahwa dalam ajaran Islam proses pengembangan nilai nilai agama dan moral pada anak usia dini dapat diterapkan dengan benar dan tepat. Hal tersebut dapat diterapkan oleh seorang guru di lembaga pendidikan maupun dilakukan oleh orangtua di rumah. Pengembangan nilai moral dan agama pada anak TK secara formal dapat dilakukan 15-20 menit setiap hari. Pelaksaanannya dapat dilakukan sebelum kegiatan belajar melalui bermain, bercerita atau bernyanyi.

Nilai-nilai moral yang dimiliki seorang anak merupakan sesuatu yang diperoleh dari luar. Anak belajar dan dibentuk oleh lingkungan mengenai tata cara seseorang harus bertingkah laku yang baik dan memahami kriteria tingkah laku yang salah atau tidak baik. Suryana (2016) menyatakan bahwa perkembangan moral dan etika pada diri anak dapat diarahkan pada pengenalan kehidupan pribadi anak dalam kaitannya dengan orang lain, misalnya mengenalkan dan menghargai perbedaan di lingkungan tempat anak hidup, mengenalkan peran gender dengan orang lain, serta mengembangkan kesadaran anak tentang hak dan tanggung jawab. 


\section{Bentuk permainan yang sangat berperan dalam perkembangan moral anak adalah bermain peran}

Hurlock (Lutfia et al., 2017) mengatakan bahwa bermain dapat mempengaruhi pembentukan moral pada anak. Palah \& Soe'aiddy (2019) menjelaskan bahwa dengan bermain anak dapat memahami konsep dan pengenalan yang diberikan guru dengan menyenangkan, sehingga anak bisa menanamkan nilai-nilai moral Islami dengan mengaplikasikannya dalam kehidupan sehari-hari. Menurut Utama (2011) melalui aktivitas bermain anak-anak dituntut untuk selalu bertindak jujur, disiplin, adil, tidak curang, tanggung jawab, fair play, menghargai teman atau lawan main, yang semuanya mengarah pada perbuatan atau tingkah laku yang baik, sehingga dengan kebiasaan tersebut dapat membuat anak-anak mengalami perubahan tingkah laku yang mengarah kepada perbuatan yang baik berarti anak mengalami perubahan moral secara positif. Sependapat dengan Rohmah (2016) kegiatan bermain merupakan kegiatan yang dapat mengembangkan berbagai aspek perkembangan anak. Pada saat bermain, anak diberikan aturan atau tata cara yang harus diikuti dan tidak boleh dilanggar. Disinilah peran bermain peran dalam perkembangan moral anak yaitu ketika anak sudah mengikuti aturan yang berlaku, maka tidak akan sulit untuk memberikan konsep-konsep yang berlaku dalam masyarakat, misalnya anak harus salim dan permaitan kepada orangtua sebelum bepergian.

Menurut Hermansyah et al. (2017) bermain peran dapat diberikan kepada anak dalam mengenalkan nilai moral kemanusiaan karena pada saat bermain peran, anak dapat memaknai apa yang diperankan, baik anak yang memerankannya ataupun anak lain yang menyimak atau menyaksikannya. Rantauwati (2014) mengatakan bahwa pada saat bermain peran dapat diselipkan nilai-nilai moral yang dapat dirasakan dan ditiru oleh peserta didik sebagai bekal kedepannya dan menjadi generasi bangsa yang bekarakter jujur, tanggung jawab, disiplin, kerja keras, kerja sama, adil, ikhlas, dan peduli. Lestariningsih (2017) memaparkan bahwa melalui bermain, anak dapat belajar berteman, bekerjasama dengan anak lain, belajar untuk berbagi, sabar menunggu giliran serta mau membantu teman yang lain.

Hasil penelitian Hidayah (2013) menunjukkan peningkatan kecerdasan natural dan spiritual melalui metode bermain. Berdasarkan hasil analisis data dan pembahasan, terjadi peningkatan kecerdasan spiritual anak pada tiga aspek yang dijadikan fokus pengembangan pada kecerdasan spiritual, yaitu aspek kemampuan mengklasifikasikan flora, fauna dan benda alam lain, kepedulian terhadap kondisi lingkungan alam, aspek doa, empati dan hidup sederhana yang meningkat cukup siginifikan. Aspek kepeduliaan, doa dan empati yang menjadi aspek yang diteliti berkaitan dengan perkembangan moral.

Hasil penelitian dari Umairoh (2015) juga menunjukkan bahwa perkembangan moral anak dapat ditingkatkan dengan metode bermain, khususnya 
bermain peran. Pada siklus I anak diberikan penjelasan terlebih dahulu sebelum melakukan sesuatu yang kemudian dipraktekkan dengan bermain peran. Guru menjelaskan terlebih dahulu kepada anak mengenai aturan berdoa sebelum dan sesudah melakukan sesuatu. Guru juga memberikan pemahaman tentang pentingnya bersikap adil dan tidak diskriminasi dalam memilih teman sehingga anak bermain bersama dengan semua teman di kelas. Pada siklus I ini anak masih berperan pasif saat bermain peran. Anak banyak bertanya kepada guru ketika akan melakukan sesuatu. Dalam tahap pembiasaan pengenalan, guru memberikan reward berupa pujian dan tepuk tangan yang akan membuat anak akan merasa dihargai bahwa perilakunya baik dan senang jika bisa bermanfaat bagi orang lain.

Hal yang sama juga ditemukan Rahmawati (2014) yang melakukan penelitian tindakan kelas dan hasilnya menunjukkan adanya peningkatan empati melalui penggunaan metode bermain peran dan alat permainan edukatif. Hal tersebut dapat dilihat dari presentase ketuntasan yang yang mengalami peningkatan pada setiap siklus, yaitu persentase nilai pratindak sebesar 28,57\%, mengalami peningkatan pada siklus I menjadi sebesar 53,57\% dan siklus II menjadi 82,14\%.

Hasil penelitian Rozali et al. (2019) menunjukkan bahwa ada perbedaan tingkat moralitas siswa SD Islam di Jakarta berdasarkan pemberian metode bermain peran pada kelompok eksperimen dibandingkan kelompok kontrol. Dari nilai mean masing-masing kelompok diperolah bahwa mean kelompok eksperimen sebesar 11.000 sedangkan mean pada kelompok kontrol sebesar 10.000, dimana mean kelompok eksperimen lebih besar dibandingkan dengan kelompok kontrol.

\section{KESIMPULAN}

Metode bermain khususnya bermain peran mampu mengembangkan moral anak seperti kemampuan anak menjelaskan mengekspresikan dan mengontrol emosi, menumbuhkan sikap empati, adil, tidak membeda-bedakan dalam berteman, memiliki kesadaran akan hak dan tanggungjawab, menghargai orang lain dan mampu menghargai cara berpikir orang lain yang berbeda dengan dirinya. Selain itu, metode bermain peran mendorong anak belajar tentang tanggung jawab, kerjasama dan gotong royong serta nilai moral lainnya. Oleh karena itu, hasil penelitian literatur ini menjadi masukan berharga bagi para orangtua dan pendidik agar melakukan stimulasi dalam bentuk bermain, khususnya bermain peran agar anak dapat mengembangkan kemampuan aspek moralnya. 


\section{DAFTAR PUSTAKA}

Ananda, R. (2017). Implementasi Nilai-nilai Moral dan Agama pada Anak Usia Dini. Jurnal Obsesi: Jurnal Pendidikan Anak Usia Dini, 1(1), 19-31. https://doi.org/https://doi.org/10.31004/obsesi.v1i1.28

Anggraini, W., \& Syafril, S. (2018). Pengembangan Nilai-nilai Moral pada Anak Usia Dini. Jurnal Pendidikan Islam Ta'lim, 1(1).

Erfayliana, Y. (2016). Aktivitas Bermain dan Perkembangan Jasmani Anak. Jurnal Pendidikan Dan Pembelajaran Dasar, 3(1), 145-158.

Farhurohman, O. (2017). Hakikat Bermain dan Permainan Anak Usia Dini di Pendidikan Anak Usia Dini (PAUD). As-Sibyan: Jurnal Pendidikan Anak Usia Dini, 2(1), 27-36.

Febriana, E. (2018). Implementasi Model Pembelajaran Sentra Bermain Peran untuk Menanamkan Nilai Moral Anak. Golden Age: Jurnal IImiah Tumbuh Kembang Anak Usia Dini, 3(2), 115-130.

Gunarsa, S. D., \& Gunarsa, Y. S. D. (2008). Psikologi Perkembangan Anak dan Remaja. Jakarta: Gunung Mulia.

Hermansyah, A. K., Suyono, \& Hasanah, M. (2017). Desain Pembelajaran Berbicara untuk Mengenalkan Nilai-nilai Moral Kemanusiaan melalui Bermain Peran. Jurnal Edukasi, 4(1), 38-42.

Hidayah, A. N. (2013). Peningkatan Kecerdasan Spiritual melalui Metode Bermain Peran pada Anak Usia Dini (Penelitian Tindakan pada Kelas 3 MI Darul Hikmah Purwokerto Tahun 2011). Jurnal Pendidikan Anak Usia Dini, 7(1), 85108.

Holis, A. (2016). Belajar melalui Bermain untuk Pengembangan Kreativitas dan Kognitif Anak Usia Dini. Jurnal Pendidikan Universitas Garut, 9(1), 23-37.

Inawati, A. (2017). Strategi Pengembangan Moral dan Nilai Agama untuk Anak Usia Dini. Al-Athfal: Jurnal Ilmiah Pendidikan Anak, 3(1), 51-64.

Khaironi, M. (2017). Pendidikan Moral pada Anak Usia Dini. Jurnal Golden Age Universitas Hamzanwadi, 1(1), 1-16.

Lestari, I. L. (2017). Pembelajaran Moral (Studi pada Siswa Kelas V SDN Sumbersekar I Kabupaten Malang). Fakultas Psikologi, Universitas Muhammadiyah Malang.

Lestariningsih, H. (2017). Pengaruh Bermain Peran Makro terhadap Perilaku Anak (Penelitian pada Kelompok B Taman Kanak Kanak Mardisiwi Tangkisan Kecamatan BayanKabupaten Purworejo Tahun 2016/2017). Fakultas Keguruan dan IImu Pendidikan, Universitas Muhammadiyah Magelang.

98 NANAEKE - Indonesian Journal of Early Childhood Education, Vol. 3, No. 2, Desember 2020 
Lutfia, D., Mardianto, \& Duryati. (2017). Pengaruh Outbound terhadap Kecerdasan Moral Anak Sekolah Dasar. Jurnal RAP (Riset Aktual Psikologi Universitas Padang), 5(2), 125-135.

Mardiono, M. (2008). Metode Penanaman Moral Untuk Anak Usia Dini. Jurnal Pendidikan, 38(2), 167-186.

Nurjanah, S. (2018). Perkembangan Nilai Agama dan Moral (STTPA Tercapai). Jurnal Paramurobi, 1(1), 43-59.

Palah, \& Soe'aiddy, M. D. (2019). Pembelajaran Nilai-nilai Moral Islami melalui Bermain, Cerita dan Menyanyi (Di RA At-Tarbiyyah Cijabon Cicantayan Kabupaten Sukabumi). WALADUNA: Jurnal Pendidikan Islam Anak Usia Dini, 2(1), 34-45.

Pranoto, Y. K. S. (2017). Kecerdasan Moral Anak Usia Dini. Edukasi, 2(1), 1-7.

Pratiwi, W. (2017). Konsep Bermain pada Anak Usia Dini. TADBIR: Jurnal Manajemen Pendidikan Islam, 5(2), 106-117.

Putri, G. K. (2018). Pembelajaran Sentra melalui Bermain Assosiative. SELING: Jurnal Psikologi Studi PGRA, 4(1), 30-43.

Rahmawati, A. (2014). Metode Bermain Peran dan Alat Permainan Edukatif untuk Meningkatkan Empati Anak Usia Dini. Jurnal Pendidikan Anak, 3(1), 382392.

Rantauwati, H. S. (2014). Pengembangan Karakter Siswa SD melalui Bermain Peran. Jurnal IImiah Guru Caraka Olah Pikir Edukatif, 1, 58-65.

Rohmah, N. (2016). Bermain dan Pemanfaatannya dalam Perkembangan Anak Usia Dini. Tarbawi: Jurnal Pendidikan Islam, 13(2), 27-35. https://doi.org/https://doi.org/10.34001/tarbawi.v13i2.590

Rozali, Y. A., Sitasari, N. W., Rahmat, I., \& Abdurrahman. (2019). Aplikasi Bermain Peran pada Siswa Sekolah dasar Islam dalam Meningkatkan Moralitas Siswa. Educultural: International Journal of Education, Culture, and Humanities, 1(2), 37-44.

Sartika, N. P. A. (2016). Pengaruh Metode Bermain Peran terhadap Pengembangan Moral Anak di Kelompok B TK Pudjinanti Kecamatan Sigi Biromaru. Bungamputi, 3(3), 1-15.

Sit, M. (2010). Optimalisasi Kompetensi Moral Anak Usia Dini. Jurnal Pendidikan Dan Kebudayaan, 16(1), 1-12.

Sugianto, B. (2018). Meningkatkan Nilai-nilai Agama dan Moral Anak melalui Bermain Peran di Kelompok B1 TK Mutiara Hati Kendari. Jurnal Riset Golden Age PAUD UHO, 1(2), 64-69. 
Suryana, D. (2016). Pendidikan Anak Usia Dini Stimulasi dan Aspek Perkembangan Anak. Jakarta: Kencana.

Utama, A. M. B. (2011). Pembentukan Karakter Anak melalui Aktivitas Bermain dalam Pendidikan Jasmani. Jurnal Pendidikan Jasmani Indonesia, 8(1), 1-9.

Yus, A. (2014). Model Pendidikan Anak Usia Dini. Jakarta: Kencana. 